\title{
Health Science Students' Perspective on Quality-of-Care-Relating Medical Professionalism [Corrigendum]
}

\author{
Binh PDU, An PL, Nguyen NA, et al. J Multidiscip Healthc. 2021;14:2229-2238.
}

Page 2231, Data Analysis section, first sentence, the text "Statistical analysis was performed using SPSS Statistics (SPSS Statistics Inc., Chicago, US) version 20.0" should read "Statistical analysis was performed using SPSS Statistics (SPSS Statistics Inc., Chicago, US) version 20.0 and STATA version 16.0".

Pages 2232 and 2234, Differences in Students' Perception of Professional Attributes Relating to QOC Between the Two Faculties section, text has been deleted from paragraphs 2 and 3, the text should read as follows:

"In both faculties, the trait Self-Awareness was reported as the most important attribute, the next being Quality of Care and Professional Habit in each year. Social Duty received the lowest mean scores, which made it the least important trait in both faculties almost at all years.

Students' perception in most attributes did not differ significantly between the two faculties in their clinical years (4th - 6th year). However, significant differences were found in the pre-clinical phase. 2nd year medical students 15 significantly assigned higher scores for Self-Awareness and Social Duty over 2nd year TM students $(\mathrm{t}(356)=-3.12$, $\mathrm{p}=0.002 ; \mathrm{t}(356)=-3.53, \mathrm{p}<0.001)$."

Page 2235, errors have been found in Table 4 . The correct Table 4 is as follows.

Table 4 Mean Scores of Professional Attributes Across Academic Years and Between Two Faculties

\begin{tabular}{|c|c|c|c|c|c|c|c|}
\hline & \multicolumn{2}{|l|}{ Medicine } & \multicolumn{2}{|c|}{ Traditional Medicine } & \multirow[t]{2}{*}{$\mathbf{P}$} & \multirow[t]{2}{*}{$\mathbf{T}$} & \multirow[t]{2}{*}{ df } \\
\hline & Mean & SD & Mean & SD & & & \\
\hline Year I $(N=4 \mid 6)$ & $n=257$ & & $n=159$ & & & & \\
\hline Social duty & 4.05 & 0.72 & 4.27 & 0.62 & 0.002 & -3.122 & 414 \\
\hline Professional habit & 4.09 & 0.74 & 4.35 & 0.62 & $<0.001$ & -3.783 & 414 \\
\hline Quality of care & 4.22 & 0.72 & 4.34 & 0.66 & 0.075 & 1.788 & 414 \\
\hline Self awareness & 4.38 & 0.77 & 4.42 & 0.67 & 0.534 & 0.577 & 414 \\
\hline Overall & 4.14 & 0.68 & 4.34 & 0.60 & 0.003 & 2.981 & 414 \\
\hline Year $2(\mathrm{~N}=358)$ & $n=247$ & & $n=111$ & & & & \\
\hline Social duty & 4.31 & 0.54 & 4.09 & 0.56 & $<0.001$ & -3.528 & 356 \\
\hline Professional habit & 4.33 & 0.59 & 4.20 & 0.60 & 0.054 & -1.937 & 356 \\
\hline Quality of care & 4.46 & 0.52 & 4.24 & 0.61 & $<0.001$ & -3.633 & 356 \\
\hline Self awareness & 4.55 & 0.54 & 4.34 & 0.63 & 0.002 & -3.121 & 356 \\
\hline Overall & 4.40 & 0.50 & 4.20 & 0.56 & 0.001 & -3.335 & 356 \\
\hline Year $3(N=202)$ & $n=142$ & & $n=60$ & & & & \\
\hline Social duty & 4.01 & 0.66 & 4.18 & 0.59 & 0.084 & $\mathrm{I} .735$ & 200 \\
\hline Professional habit & 4.09 & 0.68 & 4.20 & 0.63 & 0.316 & 1.005 & 200 \\
\hline Quality of care & 4.11 & 0.67 & 4.28 & 0.62 & 0.086 & 1.726 & 200 \\
\hline Self awareness & 4.19 & 0.73 & 4.46 & 0.69 & 0.015 & 2.454 & 200 \\
\hline Overall & 4.09 & 0.64 & 4.25 & 0.58 & 0.095 & 1.677 & 200 \\
\hline
\end{tabular}

(Continued) 
Table 4 (Continued).

\begin{tabular}{|c|c|c|c|c|c|c|c|}
\hline & \multicolumn{2}{|l|}{ Medicine } & \multicolumn{2}{|c|}{ Traditional Medicine } & \multirow[t]{2}{*}{$\mathbf{P}$} & \multirow[t]{2}{*}{$\mathbf{T}$} & \multirow[t]{2}{*}{ df } \\
\hline & Mean & SD & Mean & SD & & & \\
\hline Year $4(N=368)$ & $n=176$ & & $n=192$ & & & & \\
\hline Social duty & 4.11 & 0.59 & 4.09 & 0.63 & 0.782 & -0.277 & 366 \\
\hline Professional habit & 4.23 & 0.59 & 4.14 & 0.68 & 0.153 & -1.432 & 366 \\
\hline Quality of care & 4.27 & 0.61 & 4.20 & 0.65 & 0.268 & -1.110 & 366 \\
\hline Self awareness & 4.38 & 0.63 & 4.29 & $0.7 I$ & 0.205 & -1.270 & 366 \\
\hline Overall & 4.23 & 0.53 & 4.17 & 0.62 & 0.332 & $-0.97 \mid$ & 366 \\
\hline Year $5(N=316)$ & $n=278$ & & $n=38$ & & & & \\
\hline Social duty & 4.20 & 0.56 & 4.18 & 0.50 & 0.866 & -0.169 & 314 \\
\hline Professional habit & 4.32 & 0.57 & 4.34 & 0.53 & 0.858 & 0.180 & 314 \\
\hline Quality of care & 4.38 & 0.55 & 4.23 & 0.49 & 0.116 & -1576 & 314 \\
\hline Self awareness & 4.45 & 0.58 & 4.50 & 0.48 & 0.612 & 0.508 & 314 \\
\hline Overall & 4.32 & 0.51 & 4.30 & 0.46 & 0.795 & -0.260 & 314 \\
\hline Year $6(N=379)$ & $n=297$ & & $n=82$ & & & & \\
\hline Social duty & 4.15 & 0.58 & 4.17 & 0.69 & 0.789 & 0.267 & 377 \\
\hline Professional habit & 4.35 & 0.56 & 4.17 & 0.74 & 0.023 & -2.284 & 377 \\
\hline Quality of care & $4.4 I$ & 0.56 & 4.28 & 0.67 & 0.072 & -1.805 & 377 \\
\hline Self-awareness & 4.57 & 0.60 & 4.43 & 0.72 & 0.090 & -1.699 & 377 \\
\hline Overall & 4.33 & 0.50 & 4.24 & 0.66 & 0.167 & -1.385 & 377 \\
\hline
\end{tabular}

Page 2236, Discussion section, left column, text has been deleted from paragraph 2, the text should read as follows:

"This is the first study in Vietnam to reveal both Medical and TM students' perceptions on QOC-relating to professional attributes. No differences were found between the faculties in the order of these 4 attributes, being from the most to the least important, which was Self-Awareness, Ensuring QOC, Professional Habit and Social Duty (Figure 1)".

Page 2237, Discussion section, paragraph 4, last sentence, the text "Last but not least, Professional Habit referring to collaboration should be emphasized for the junior TM students due to their extreme underestimation of this trait" should read "Last but not least, Professional Habit referring to collaboration should also be emphasized for the TM students due to their underestimation of this trait".

The authors apologize for these errors and state that these corrections do not change the scientific conclusions of the article in any way.

\section{Publish your work in this journal}

The Journal of Multidisciplinary Healthcare is an international, peer-reviewed open-access journal that aims to represent and publish research in healthcare areas delivered by practitioners of different disciplines. This includes studies and reviews conducted by multidisciplinary teams as well as research which evaluates the results or conduct of such teams or healthcare processes in general. The journal covers a very wide range of areas and welcomes submissions from practitioners at all levels, from all over the world. The manuscript management system is completely online and includes a very quick and fair peer-review system. Visit http://www.dovepress.com/testimonials.php to read real quotes from published authors. 